Textos 



\title{
Paradoxos do nacionalismo literário na América Latina
}

\author{
LETLA PERRONE-MOISÉS
}

$\mathrm{C}$

OMPARADAS Às grandes literaturas do Oriente e da Europa, as literaturas latino-americanas têm uma história curta: 500 anos, se considerarmos o período de colonização espanhola e portuguesa, ou um pouco menos de dois séculos, se quisermos fazer coincidir a autonomia literária com a independência política das nações. Criadas e desenvolvidas em línguas de antigas culturas, ou como prolongamentos excêntricos das grandes literaturas européias, as literaturas latino-americanas foram forçadas, desde o início, a enfrentar a questão identitária, a se debater entre as instâncias do Mesmo e do Outro. Como todas as literaturas coloniais, dir-se-ia, mas com especificidades que vale a pena lembrar para não cair em certo discurso pós-colonial (1) que só lhe convém em parte.

Considere-se, primeiramente, que falo aqui das literaturas constituídas em espanhol e em português, afastando de meus propósitos as anteriores à Descoberta e aquelas que continuaram a ser feitas em línguas indígenas. $\mathrm{O}$ fato de não considerar aqui essas literaturas não significa, obviamente, que não sejam importantes, mas simplesmente que, na qualidade de literaturas em línguas mortas ou línguas de resistência, elas colocam problemas que ultrapassam meu assunto. Afasto também de minhas considerações a literatura do Québec e as literaturas caribenhas que, porquanto também latino-americanas e apresentando certas afinidades com as de origem ibérica, constituíram-se e prosseguem em circunstâncias particulares que não cabe aqui levantar.

As especificidades das literaturas ibero-americanas decorrem de certas condições históricas que as distinguem das outras literaturas coloniais, inclusive as da América do Norte. Para começar, lembremos alguns dados bem conhecidos. Até o século XIX, os países da América Ibérica foram explorados pela Espanha e por Portugal, como reservas de onde se extraíam minerais e matérias primas. Depois da Independência dos Estados Unidos e da Revolução Francesa, os movimentos de libertação eclodiram em todos esses países, como aspiração das oligarquias locais, com o apoio da França e sobretudo da Inglaterra, que tinha o maior interesse em se livrar de seus rivais comerciais nessa parte do globo. A participação das classes populares - índios, negros e mestiços - tinha razões imediatas e locais, e um alcance tão heróico quanto circunstancial para o resultado da luta.

A oligarquia dos países latino-americanos tinha uma formação cultural européia, e os princípios e valores em nome dos quais ela lutava eram os que a Europa difundia a partir da Revolução Francesa. Entre 1810 e 1824 os países latino-americanos conquistaram, um após outro, sua independência. Essa libertação 
foi favorecida e acelerada, nas colônias espanholas, pela prisão do rei da Espanha efetuada pelas forças napoleônicas. O caso do Brasil foi diferente porque o rei de Portugal, Dom João VI, fugindo dos exércitos de Napoleão, refugiou-se com sua corte no Rio de Janeiro. Assim, caso único e ambíguo, o Brasil teve sua Independência proclamada um pouco mais tarde pelo futuro imperador D. Pedro I, que voltaria depois a Portugal para ali reinar. Tal fato criou a imagem ou a ilusão de uma separação amigável, sem demasiados rancores contra a Metrópole, substituídos por certo menosprezo com relação à fraqueza e à dissolução interna da mesma. O Uruguai, pequeno território que fora durante muitos anos um joguete da metrópole espanhola e dos países vizinhos, só se definiu como República em 1828. A independência conquistada pelos países latino-americanos, no início do século XIX, foi uma independência formal. Ao sair do jugo ibérico, eles caíram sob o jugo econômico das grandes potências européias, mais tarde sob a dominação dos Estados Unidos, do Banco Mundial, e mais recentemente, da Nova Ordem Mundial.

Tudo isso teve e tem conseqüências culturais e literárias. Certos fatos devem ser considerados se se quiser compreender em que as literaturas latino-americanas se distinguem das outras literaturas coloniais e pós-coloniais. A identidade cultural desses países se constituiu, e em alguns casos está ainda em processo de constituição, não como a recuperação de uma identidade originária, autóctone (na maioria dos casos apagada pela colonização), mas como uma diferença no seio da identidade: uma relação filial. Por mais violento que seja o desejo de libertação, permanece uma ligação indissolúvel entre essas culturas, e essas literaturas, com as metropolitanas. Assim, as relações das literaturas latino-americanas com as literaturas européias não são o enfrentamento de tradições diversas, mas constituem um "caso de família". Doris Sommer, estudando os fundamentos da ficção latinoamericanas, usa apropriadamente a expressão "a family affair" (2).

Os primeiros letrados da América Latina, formados nas universidades das metrópoles, sentiam-se, em seus próprios países, como europeus exilados. As idéias, os sentimentos, as instituições européias que eram doravante seus, pareciam deslocados em regiões onde a imensidade territorial, o clima e a natureza lhes eram hostis, ou pelo menos resistentes. Os poetas brasileiros do século XVIII queixavam-se de nossos rios, à beira dos quais nenhuma ninfa resistiria ao calor e aos mosquitos.

A tópica do americanismo como desterro aparece em vários autores latinoamericanos. No Brasil, ela teve sua mais famosa formulação nas palavras de Sérgio Buarque de Holanda: "Trazendo de países distantes nossas formas de convívio, nossas instituições, nossas idéias, e timbrando em manter tudo isso em ambiente muitas vezes desfavorável e hostil, somos ainda hoje uns desterrados em nossa terra" (3).

Dois séculos depois dos poetas árcades e 50 anos depois do historiador brasileiro, Jorge Luis Borges declarava ainda: "Sou um europeu nascido no exílio" (4).

Nossa diferença, com relação a outros povos colonizados pelos europeus, consiste no fato de que em muitas regiões nada restou das culturas primitivas, e o 
pouco que restou foi abafado. Assim, os primeiros latino-americanos que refletiram sobre sua identidade se encontraram numa indeterminação constitucional. É o que constatava, em 1819, o Libertador Simón Bolivar: "Ao desprender-se da monarquia espanhola, a América se encontrou semelhante ao Império Romano, quando aquela enorme massa caiu dispersa em meio ao mundo antigo. Cada desmembramento formou, então, uma nação independente, conforme sua situação e seus interesses. Com a diferença, porém, de que aqueles membros voltaram a restabelecer suas primeiras associações. Nós, nem ao menos conservamos o vestígio do que fomos em outros tempos; não somos europeus, não somos indígenas; somos uma espécie média entre os aborígenes e os espanhóis. Americanos por nascimento, europeus por direito, achamo-nos no conflito de disputar aos naturais o título de posse e o direito de nos mantermos no país que nos viu nascer, contra a oposição dos invasores; assim, nosso caso é o mais extraordinário e complicado" (5).

Outro fator de complicação decorrente dessa necessidade de se desenvolver à imagem e semelhança do Outro, num lugar desprovido do passado do Outro e despojado do seu próprio passado, foi a dupla missão de que se sentiram investidos os primeiros escritores latino-americanos: a missão de criar, ao mesmo tempo, uma pátria e uma literatura (6). A literatura teve um papel efetivo na constituição de uma consciência nacional e, assim, na construção das próprias nações latinoamericanas. Não é por acaso que a lista de presidentes latino-americanos que foram também escritores é tão longa (7).

Além do mais, tudo se fez sob e para o olhar da Europa, à qual os países da América Latina queriam provar seu valor como nação e como cultura, uma sendo então sinônimo da outra. Muito freqüentemente, eram os mesmos homens que tomavam as armas e a pena, estando esta forçosamente engajada nas questões sociais e políticas. Árdua missão que pesava sobre seus escritos, proibindo-lhes, como observa Antonio Candido, o vôo livre da imaginação e as pesquisas formais desinteressadas. Entrave que foi sentido por numerosos escritores da América Latina, entre os quais o argentino Ernesto Sábato: "Um escritor nasce em França e acha, por assim dizer, uma pátria feita: aqui ele deve escrever fazendo-a ao mesmo tempo" (8).

Numerosos estudos sobre o nacionalismo demonstraram que a nação é um conjunto de imagens, e que ela se constitui graças a metáforas. Algumas metáforas utilizadas nos discursos identitários da América Latina nos permitem captar as dificuldades da constituição de sua auto-imagem, e verificar que essa imagem depende sempre do outro europeu, quer seja para imitá-lo, quer para rejeitá-lo.

Um par de metáforas surgido logo após a descoberta foi o que opõe a infância americana à velhice européia. Novo oposto a Velho eram já os qualificativos expressos na denominação do Novo Mundo. Novidade e infância são valores positivos, se os considerarmos do ponto de vista da força vital; mas eles supõem também que o novo carece de história e portanto de cultura, que a criança é menor, que ela deve amadurecer para se tornar adulta como seus pais. O qualificativo novo, largamente utilizado pelos europeus na nomeação das terras descobertas e 
das cidades fundadas, já indicava a intenção de reduzir-lhes a alteridade, de impor a essas terras novas uma história que seria a repetição da sua, ou uma história recomeçada. Numerosos pensadores europeus viram a América como a oportunidade, para a Europa, de uma nova juventude, e essa pretensão, por mais lisonjeira que possa parecer, foi difícil de carregar para os americanos. A situação é semelhante àquela dos pais que transmitem aos filhos a obrigação de realizar seus próprios sonhos frustrados.

Assim que os latino-americanos começaram a refletir eles mesmos sobre sua identidade, as metáforas criadas foram autodepreciativas ou pelo menos conflituosas. Essas metáforas tomaram a forma de oposições que mostram, claramente, o reconhecimento da inferioridade e da dependência com relação à Europa. A mais célebre é a do argentino Sarmiento, que em 1845 caracterizou a América como Barbárie contraposta à Civilização européia (9). Essa oposição já se encontrava esboçada em A Tempestade, de Shakespeare, nas figuras de Caliban e Ariel. Em 1900, o uruguaio Rodó retomaria o tema, em outros termos, opondo então a civilização greco-romana à barbárie norte-americana (10). Como observou Richard Morse, os latino-americanos são, de todos os povos, os únicos que aplicaram o qualificativo bárbaro a eles mesmos, e não aos outros, o que contraria a própria etimologia da palavra (11).

O encontro (ou enfrentamento) da Civilização com a Barbárie foi alegorizado por numerosos romancistas, como o argentino José Mármol (Amalia, 1851) e o brasileiro José de Alencar ( $O$ Guarani, 1857 e Iracema, 1865). A questão seria retomada por Euclides da Cunha em Os sertões (1902) e por muitos outros escritores latino-americanos, como o venezuelano Rómulo Gallegos (Doña Bárbara, 1929).

Outra oposição, igualmente pejorativa para a América, é a da aldeia ao mundo. José Martí começa seu célebre texto Nuestra América por esta consideração: "O aldeião pensa que o mundo inteiro é a sua aldeia" (12). Os conceitos mais recentes de centro e periferia, com os quais certos ensaístas latino-americanos pensam os problemas literários, é uma retomada dessa reflexão de Martí e tem o inconveniente de atribuir, como ele, a precedência e a legitimidade, enfim, todas as vantagens ao centro. Pensar a literatura a partir da idéia de um Centro, no qual as idéias, as formas artísticas e as instituições sociais estariam idealmente afinadas, leva a identificar, na periferia, apenas os desconcertos sociais, sem ver os acertos estéticos. Na verdade, se algumas dessas idéias e formas surgem e permanecem como deslocadas e caricaturais, outras adquirem, no novo meio, novos contornos e novas funções. A literatura mexicana não precisou esperar a Independência para ter Sor Juana Inés de la Cruz, nem a brasileira para ter a de Gregório de Matos, e ambos deram ao Barroco uma alta e original realização.

Em todas as metáforas e qualificativos utilizados pelos latino-americanos, podemos ver o auto-reconhecimento de seu caráter atrasado e subdesenvolvido, nos sentidos biológico, econômico e cultural do termo. O nacionalismo, nessas condições, só pode ser vivido como ressentimento e recriminação de si mesmo e do outro, numa oscilação entre o ufanismo e o complexo de inferioridade. 
O nacionalismo, como apego de um grupo a seu território e a seus valores, não é uma invenção do século XIX. Ele sempre existiu sob a forma de patriotismo. Mas foi no século XIX que o nacionalismo adquiriu a força de um conceito e, por uma coincidência histórica, foi naquele momento que os povos latino-americanos $\mathrm{o}$ acolheram. A conquista da independência pelos países latino-americanos coincidiu com o Romantismo literário. Tal foi também o caso de várias nações européias, mas estas possuíam um passado de vários séculos, traços culturais particulares e sentimentos patrióticos antigos a partir dos quais elas podiam forjar uma identidade (13). Na América Latina, não se tratava de dar uma forma a elementos preexistentes, mas de verdadeiramente inventar essa forma, destacando-se das antigas metrópoles.

Do Romantismo nossos escritores receberam, com entusiasmo, o conceito de nação e o sentimento nacionalista. E foi então que as oposições originárias, pelas quais a América Latina tentava se definir face à Europa, desembocaram em paradoxos. O primeiro consiste exatamente na adoção do conceito de nacionalismo em literatura, o que Borges exprimia com humor: "O culto argentino da cor local é um culto europeu recente, que os nacionalistas deveriam recusar posto que é estrangeiro" (14). Coisa de que já desconfiava o nacionalista Policarpo Quaresma: "E, bem pensando, mesmo na sua pureza, o que vinha a ser a Pátria? (...) Lembrou-se de que essa noção nada é para os Menenanã, para tantas pessoas... Pareceu-lhe que essa idéia como que fora explorada pelos conquistadores por instantes sabedores das nossas subserviências psicológicas, no intuito de servir às suas próprias ambições...” (15).

\section{Paradoxos nacionalistas}

As reivindicações nacionalistas nascem e vivem da rejeição de um outro opressivo, que impõe seus princípios e seus valores, apagando, ao mesmo tempo, os de uma cultura determinada. Esse outro é um invasor, um colonizador, um explorador. Na América Latina, o nacionalismo nascido com as Guerras de Independência não perdeu seu caráter belicoso depois da conquista da autonomia política, porque restou, depois dela, a dependência econômica e outra ainda mais insidiosa porque incorporada: a dependência cultural vivida pelos latino-americanos como uma fatalidade, à medida em que a cultura e as próprias línguas que lhe restaram foram as do colonizador. O outro, do qual desejaríamos nos libertar, estava em nós mesmos: "Me sinto branco, fatalizadamente um ser de mundos que nunca vi", diria Mário de Andrade (16).

Nosso nacionalismo voltou-se então contra inimigos mal definidos, oscilando segundo as circunstâncias, misturando etnia, cultura, política e economia, atribuindo aos desígnios funestos de outros todas as nossas dificuldades em encontrar um lugar na cultura internacional. Ora, a busca de uma essência nacional, visando a conquistar um lugar honroso no conjunto das nações, esbarra sempre no paradoxo de reforçar o localismo e o provincianismo, embora o objetivo maior seja o de provar o valor universal dessa particularidade.

Os nacionalismos literários latino-americanos, do Romantismo aos dias de 
hoje, têm essa característica de uma reivindicação que não conhece muito bem os limites dos direitos e das recusas, correndo sempre o risco de misturar razões políticas e econômicas com razões estéticas, e de querer eliminar um inimigo que, do ponto de vista da história cultural, é constitutivo de sua identidade.

$\mathrm{Na}$ busca da criação de culturas nacionais próprias, as jovens nações latinoamericanas encontraram-se pois em situações paradoxais, sem que tivessem, no entanto, a consciência imediata desses paradoxos. Tal característica aparece claramente ao longo de todo o século XIX. Como a dependência cultural tem razões e resultados mais sutis, e por vezes independentes da dependência política e econômica, o primeiro paradoxo dos nacionalismos literários apareceu nas relações dessas novas literaturas com a velha literatura francesa.

Por que a França? Sem entrar na complexa questão da avassaladora influência da cultura francesa, desde o século XVII, sobre numerosas nações que nunca dependeram dela política ou economicamente (prova do que foi afirmado), podemos avançar uma hipótese no que nos concerne. Por que a França que, apesar de algumas tentativas desastradas, nunca conseguiu colonizar, no sentido próprio, a América Latina? Primeiro, porque justamente a França não foi nossa colonizadora histórica, e isso permitiu todas as idealizações a seu respeito. Em seguida, porque ela representava, no século XIX, a pátria da Revolução e da Liberdade, que escolhemos como oposta às metrópoles ibéricas. No entanto, naquele momento, as antigas metrópoles espanhola e portuguesa estavam elas mesmas afrancesadas, $\mathrm{o}$ que tirava de nossa opção pela França significativa parte de sua originalidade. Um bom exemplo disso nos é dado por Dom João VI que, corrido por Napoleão e instalado no Brasil, chamou imediatamente uma Missão Francesa, científica e artística, para ilustrar a colônia transformada em sede do Reino. Os pintores dessa Missão usaram, para retratar Dom João VI, a mesma estética neoclássica que tinham aprendido e usado para retratar Napoleão.

O nacionalismo romântico, que impregnou em seguida nossas literaturas, vinha ele mesmo da Europa, via França. A atenção que os escritores prestaram então à natureza americana e aos aborígines vinha diretamente da obra de Chateaubriand, reveladora de uma matéria literária que eles tinham a domicílio. Os índios constituíam uma matéria romanesca e poética com múltiplas vantagens: eram aquela origem mítica necessária a toda nação; eram nossa parte não-européia; já quase exterminados, prestavam-se a todas as fantasias; serviam de biombo para os negros, que estavam demasiadamente próximos e suscitavam a questão espinhosa da escravidão, cuja abolição só se tornou tema literário quando iminente, por consenso e pressão internacional.

Ao longo de todo o século XIX a França foi o farol (metáfora recorrente nos discursos latino-americanos de então) cuja luz nos guiou. Recebemos da França até mesmo a denominação sob a qual nos reconhecemos, a de América Latina. Como se sabe, foi Napoleão III que, preocupado com assegurar a influência da França nas nações ameaçadas de cair sob a dominação econômica e cultural anglosaxônica, promoveu a ideologia da Latinidade, que lhe asseguraria a anexação do México e a aliança dos outros países latino-americanos. Os objetivos políticos de 
Napoleão III não foram alcançados, mas a vitória cultural da França estava já assegurada. Sob a influência do positivismo de Auguste Comte, definimos os ideais, as instituições e os símbolos de nossas jovens repúblicas (como a divisa da bandeira do Brasil, por exemplo).

Na virada do século Paris era, sem contestação, a capital cultural da América Latina (17). A viagem a Paris, real ou imaginária, era um reencontro e uma busca de identidade. A volta à fonte européia de eleição (deslocada, com relação às fontes viscosas das metrópoles ibéricas) era, ao mesmo tempo, uma tomada de distância necessária para que a origem se tornasse visível em sua identidade própria. Assim, em 1924, Oswald de Andrade descobriu o Brasil através de uma janela da Place Clichy, experiência que foi a de numerosos exilados voluntários ou forçados. Todo exílio permite essa distância cognitiva; mas no caso dos latino-americanos, propiciava tanto uma volta à origem de suas culturas quanto a descoberta das diferenças, devolvendo-os aos seus países mais atentos a eles do que antes da viagem.

No momento da eclosão das vanguardas européias, foi novamente a França (epicentro do sismo) que revelou aos latino-americanos as possibilidades estéticas de suas culturas. A valorização da arte primitiva foi assimilada, em conhecimento de causa, pelos países latino-americanos que possuíam, em seu patrimônio, manifestações ainda vivas da arte indígena e contribuições ativas dos negros africanos. As vanguardas eram cosmopolitas. Os vanguardistas latino-americanos pretenderam realizar a proeza de serem, ao mesmo tempo, nacionalistas e cosmopolitas. Essa contradição, na verdade, já estava colocada e não resolvida no conceito de nação difundido pelo Iluminismo. $\mathrm{O}$ recurso à inspiração primitivista permitiu às nossas vanguardas uma solução para esse problema.

À medida que as culturas e literaturas locais se constituíam e se afirmavam, as relações idílicas com a França começaram a azedar, e numerosas vozes se levantaram contra essa já então chamada dependência. Desde o fim do século XIX, polêmicas inflamadas eram travadas entre partidários de uma literatura autenticamente nacional e partidários de uma literatura aberta às influências européias. Bárbaros opunham-se a Civilizados: o chileno Andrés Bello contra o argentino Sarmiento, Alencar contra Nabuco.

No decorrer do século XX, os discursos antifranceses dos intelectuais nacionalistas intensificaram-se e, paulatinamente, à medida que declinava, em toda parte, a influência francesa e crescia a norte-americana, transformaram-se em discursos contrários a toda influência estrangeira emanada dos países hegemônicos, por definição opressivos. Constituiu-se então, em alguns intelectuais, um ideal cultural latino-americano que ainda persiste em nossos dias e que se esteia em dois enganos: a pretensão a uma cultura própria, isenta de toda contaminação estrangeira, e a concepção de uma América Latina uniforme, culturalmente homogênea. $\mathrm{O}$ projeto de uma união latino-americana face às potências hegemônicas, perfeitamente compreensível quando se trata de política e de economia, produz amálgamas e equívocos quando se trata de cultura e de literatura. 
Primeiramente, nenhuma cultura, nenhuma literatura - a começar pelas das nações hegemônicas - se constituiu ou vive sem contaminações. O que ocorre é exatamente o contrário, e isso é um universal antropológico (18). A cultura de Roma não existiria sem a Grécia, a do Japão sem a China etc. As próprias metrópoles colonizadoras - Espanha e Portugal - tinham culturas resultantes de numerosas assimilações. Além disso, é preciso considerar que os americanos, desejosos de recuperar as fontes puras de antes da Descoberta, se esquecem de que estas não eram puras (as culturas pré-colombianas eram resultado de confrontos, aniquilações e assimilações), e que a América, como um continunm geográfico e cultural, é uma invenção dos descobridores e conquistadores europeus. E que, por maior que seja nosso desejo de reencontrar essas fontes, elas estão perdidas ou soterradas há séculos.

Ora, a América Latina é cria da cultura européia e, em vez de rejeitar essa filiação, deve reivindicá-la, ao mesmo tempo que deve reivindicar tudo o que culturas indígenas, africanas, e outras mais recentemente, trouxeram à sua constituição. A exaltação ou a recusa de cada uma dessas constituintes de nossa identidade pode ter razões ideológicas, mas nunca terá fundamentação cultural. A diversidade é nossa riqueza. Querer fazer um bloco cultural homogêneo de regiões tão diversas como o Rio de la Plata, tão europeizado, o Caribe e o Brasil, tão africanizados, o México, tão marcado por suas resistentes raízes índias, é querer reduzir essa magnífica complexidade cultural a uma falsa imagem.

O desejo de uma imagem homogênea da América Latina conduz, às vezes, à valorização do folclore e da pobreza como especificamente latino-americanos. Mas assim como a América Latina é complexa em sua constituição étnica, ela é diversa em seu desenvolvimento, e a literatura demonstra tal aspecto. A Macondo de Garcia Márquez e o sertão de Guimarães Rosa são tão latino-americanos quanto a Paulicéia de Mário de Andrade, a Havana de Cabrera Infante ou a Buenos Aires de Borges.

A imagem de uma América Latina única, pobre mas alegre, ignorante mas vital, é a que convém, justamente, ao olhar das culturas hegemônicas. Desde a Descoberta, nós nos vimos pelo olhar do Outro. As primeiras descrições das terras americanas as identificavam ao Paraíso; os europeus se espantavam com a grandiosidade e a exuberância da natureza americana, que só é prodigiosa em comparação com a natureza européia, desde muito domesticada, mas não para os nativos da América que, em seu quotidiano, deviam lutar com essa natureza toda poderosa. O real americano só é maravilhoso se o considerarmos do ponto de vista não americano; para os americanos, é apenas o real.

A mesma obrigação imposta pela Europa aos latino-americanos, a de ser uma reserva vitalizada de sua antiga cultura, pesou e pesa sobre a natureza americana, que deve ser preservada já que a da Europa foi há muito sacrificada. Se é óbvio, para a preservação do homem em geral, que a natureza deve ser preservada, não é porém justo que tal obrigação (e a culpa decorrente) nos seja imposta. A natureza, como se sabe, é um conceito cultural, já que é a cultura que constitui uma natureza através de mediações ideológicas e da atribuição de sentido. A natu- 
reza americana vista pelo olhar europeu foi concebida como natureza natural, e como tal foi aceita pelos latino-americanos. Assim, numa nova oposição, somos inclinados a nos identificar à Natureza, deixando à Europa o privilégio da Cultura. Pouca história e muita geografia, assim nos vêem e, pior, assim nos vemos.

O grande problema é que esses lugares-comuns europeus sobre a América Latina têm uma parte de verdade. Apesar de todas as misérias, os países latinoamericanos têm, de fato, uma natureza exuberante, e seus habitantes uma vitalidade, uma imaginação e um gosto pela festa que se devem a certos arcaísmos preservados, ao simples desejo de sobreviver ou a uma venturosa inconsciência. A questão não é tanto a de nos desfazermos dessas características, que agradam aos outros, mas de vivê-las com lucidez e não como uma compensação do que falta ao outro.

As dificuldades identitárias manifestaram-se e manifestam-se na historiografia literária latino-americana. Nossas jovens literaturas nasceram em velhas línguas, em que já existia uma tradição literária. Como observa Octavio Paz: "Em geral, a vida de uma literatura se confunde com a da língua na qual ela é escrita; no caso de nossas literaturas, sua infância confunde-se com a maturidade da língua. Nossos primitivos não vêm antes, mas depois de uma tradição de séculos. Nossas literaturas começam pelo fim" (19).

Se escrevermos a história das literaturas latino-americanas como um apêndice da história das literaturas das línguas mães, mantendo-as como um paradigma a ser alcançado, estaremos dentro de uma concepção evolucionista da literatura, e tenderemos a considerar as primeiras manifestações coloniais como infantis e canhestras. Se considerarmos que, em determinado momento, essa história se torna autônoma, teremos dificuldades em situar precisamente esse corte. Se situarmos esse começo no momento da independência política, por exemplo, apenas retardaremos sua infância. Ora, essas literaturas não tiveram um começo desprovido de tradição; por outro lado, o valor estético das obras não depende da situação política ou social dos seus produtores.

A história das literaturas latino-americanas, comparada às das línguas mães, apresenta constantes defasagens. Os anacronismos foram inevitáveis, mas estes não representavam sempre atrasos, à medida em que se efetuavam em sincronia com outras informações, mais recentes, provocando curto-circuitos originais que abriam às velhas formas possibilidades de desenvolvimento abandonadas ou nunca exploradas pelas literaturas metropolitanas. As próprias línguas adquiriram, na América, esse caráter duplo de reserva arqueológica e prática revitalizante.

Se nossa história política e econômica pode ser contada de modo linear, nossa história cultural e literária acomoda-se mal à simples diacronia. Os melhores autores latino-americanos sempre foram, ao mesmo tempo, depositários das velhas formas européias e exploradores ousados do possível futuro das mesmas. Os anacronismos de nossos escritores foram, muitas vezes, anacronismos prospectivos (20). Entre os numerosos autores que assinalaram tal aspecto estratificado ou aluvial das literaturas latino-americanas, podemos lembrar Alejo Carpentier (21), que o 
explorou em sua ficção, e Angel Rama (22), que o examinou em termos de problema historiográfico.

A América (e não falo aqui apenas da América Latina) é, ao mesmo tempo, memória e projeto europeu, nostalgia de um passado perdido e prefiguração de um possível futuro. É com esses dois verbos - sentir saudades e prefigurar - que Lezama Lima conclui seu ensaio La expresión americana (23). Mais recentemente, tais particularidades de nossa história literária foram reexaminadas por Haroldo de Campos. Opondo um nacionalismo modal ao nacionalismo ontológico, o autor propõe "o nacionalismo como movimento dialógico da diferença, e não como unção platônica da origem"; conseqüentemente, "a historiografia como gráfico sísmico da fragmentação eversiva, antes do que como homologação tautológica do homogêneo" (24).

Considerando essas mesmas particularidades da história literária latino-americana, Ana Pizarro observa que tais literaturas são "sistemas que expressam tempos culturais diferentes e às vezes antagônicos", "linhas plurais em relação, em seus complexos movimentos de contato, em seus jogos de hegemonias e subalternidades, de paralelismos, de defasagens, de recusas ou de integração", "literatura de tempos diferentes que se articulam em espaços de outra coerência" (25).

\section{Do paradoxo à para-doxa}

A questão da identidade latino-americana é um topos obsessivo de nossa ensaística. Minha intenção, aqui, não poderia ser a de discutir, nem ao menos de referir as dezenas de autores que se debruçaram sobre a questão, e as milhares de páginas a ela dedicadas, mas simplesmente a de levantar alguns paradoxos nascidos dessa longa reflexão. Se as primeiras reflexões dos latino-americanos sobre sua identidade se colocavam em termos de comparação com a Europa, no decorrer de nosso século numerosos pensadores a colocaram em termos de mestiçagem cultural.

Um novo paradoxo aparece então. De modo geral, o nacionalismo, para afirmar-se, rejeita o outro e acaba por tender ao racismo. Um nacionalismo que reconhece e exalta a mestiçagem defronta-se com o problema da definição dos limites na acolhida da alteridade. A mestiçagem, como ideologia, apresentou-se freqüentemente como racismo disfarçado. No fim do século XIX, certos pensadores latino-americanos encararam a mestiçagem como possibilidade de branqueamento e melhoria da raça. No Brasil, a aliança do branco com o índio, idealizada porque remota, era mais facilmente admitida do que a aliança com o negro, demasiadamente presente e visivelmente outro. No século XX, sobretudo depois da obra de Gilberto Freyre, Casa grande e senzala (1933), a situação inverteu-se e os intelectuais passaram a declarar suas origens negras. Essa assunção lhes dava boa consciência, e os marcava como verdadeiros brasileiros, diversos dos novos imigrantes europeus ou orientais. No afã da busca de uma identidade totalmente liberada da Europa, alguns intelectuais inverteram o sinal e chegaram a um racismo antibranco, declararando, por exemplo, que Argentina e Uruguai eram demasiadamente europeus para serem considerados América Latina. Foi o caso de Darcy Ribeiro, em um momento pouco feliz (26). 
Independentemente do que possam especular os intelectuais a respeito, a mestiçagem é um fato consumado na América Latina e, em termos culturais e artísticos, produz resultados originais. Vários de nossos escritores encararam essa mestiçagem como transculturação, como uma síntese que não seria uma assunção soberana e tranqüila do Ser, mas uma síntese sempre provisória, em processo, aberta a novas aventuras do ser americano. Apenas a título de exemplo, lembrarei algumas dessas propostas.

Em 1928, Oswald de Andrade propôs uma solução para o problema das influências estrangeiras que consistiria, não na recusa, mas na incorporação deliberdada das mesmas. A metáfora utilizada foi a da Antropofagia praticada pelos índios. Ao devorarem ritualmente seus inimigos, os habitantes primitivos do Brasil acreditavam assimilar suas qualidades; o que os obrigava a uma avaliação prévia das mesmas (instância crítica), e devia resultar no reforço das capacidades do devorador (instância assimiladora). Transpondo tal prática ao domínio cultural da modernidade brasileira, Oswald considerava que, pela dupla operação de assassinato e devoração do pai europeu, o filho resolveria seu complexo de Édipo, transformaria o Tabu em Totem. Essa proposta tinha a vantagem de substituir o que mais tarde seria chamado de angústia da influência (27) por uma apropriação voluntária da mesma.

A metáfora de Oswald e seu desenvolvimento teórico buscavam resolver a contradição colocada pelo duplo movimento da vanguarda brasileira, nacionalista e cosmopolita. Oswald não foi um pensador consistente, mas sua especulação de artista é astuciosa, cheia de humor e prenhe de sugestões que ainda hoje não se esgotaram. Mais tarde ele prosseguiria essas reflexões fazendo o elogio do matriarcado das sociedades primitivas, atribuindo ao messianismo e ao patriarcado todas as infelicidades do Ocidente. Nesse elogio do matriarcado, Oswald também se revela como um nacionalista atípico. Todos os estudos sobre o nacionalismo mostram que este, em geral, procede de um imaginário masculino, cujos valores são a força, o trabalho e a guerra. O imaginário que Oswald gostaria de recuperar seria, ao contrário, feito de doçura e de ócio.

Em tom bem diverso, mas no mesmo espírito, Octavio Paz sempre tratou a questão das influências européias em termos de assimilação e transformação. Em El laberinto de la soledad (28) ele representava o nascimento do México como o resultado da violentação de uma índia por um europeu. Qualquer que fosse o rancor com relação ao pai, o filho deveria não apenas reconhecer essa filiação mas exigir a herança. O parricídio nunca pareceu, a Octavio Paz, uma solução. Segundo ele, renunciar à influência européia seria renunciar a uma parte de nós mesmos, porque sem ela nossa arte e nossa literatura não seriam o que são (29). No mesmo sentido, observou Ernesto Sábato: "Corremos o risco de substituir os males que nos trazem freqüentemente a simples imitação da cultura européia pela rejeição da grande e preciosa herança que essa cultura supõe, o que seria uma calamidade quase pior do que a precedente" (30).

E retoma a antiga questão da barbárie para inverter seu enfoque: "É provável que nossa própria barbárie, e a convicção dos doutores de nossa Organização 
de que devíamos olhar para a Europa como para um paradigma, nos tenha mantido mais lúcidos com relação a seus valores culturais do que os próprios europeus" (31).

Lezama Lima, em La expresión americana, ensaio em que a ficção se funde à análise e o imaginário ao real, concebe a literatura ocidental como um banquete ao qual o americano viria trazer o toque final e refinado do tabaco. A América foi encarada por Lezama como um "espaço gnóstico", aberto à "fecundação" dos elementos hispânicos, eles mesmos resultados de inúmeras fecundações anteriores. Jorge Luis Borges, finalmente, encarou essa questão com sua peculiar ironia. Lembrando que os irlandeses, sentindo-se diferentes, inovaram a literatura inglesa, ele acrescenta: "Creio que os argentinos, os sul-americanos em geral, estamos numa situação análoga. Podemos tratar todos os temas europeus sem superstições, com uma irreverência que pode ter, e já tem, conseqüências afortunadas. Devemos pensar que nosso patrimônio é o universo" (32).

Borges também observa que podemos ser europeístas, enquanto os europeus só podem ser europeus. Os nacionalistas, em geral, são desprovidos dessa auto-ironia. É o que observa Terry Eagleton: a auto-ironia seria o reconhecimento lúcido do condicionamento conceitual de todo nacionalismo à existência e à força do Outro (33).

Apesar das diferenças, tais propostas têm traços comuns. São inclusivas e não exclusivas, acolhedoras e pacíficas. Como se sabe, os nacionalismos tendem a exacerbar-se até a guerra. Mas desde as Guerras de Independência, os discursos nacionalistas latino-americanos deixaram de ser belicosos; as bombas são aí puramente retóricas. As metáforas identitárias latino-americanas são no mais das vezes eróticas, fazem apelo à cena primitiva da união Europa-América. Permanece porém, em algumas dessas metáforas, a lembrança de uma violência - a invasão, o estupro - que provoca uma resposta igualmente agressiva - o canibalismo, a apropriação ilícita (34). A questão dolorosa de nossas origens é colocada com vistas a uma solução, mas não é esquecida. Existe sempre, nos ensaios sobre nossa identidade, uma tensão de base: nossa relação com o Velho Mundo que nos invadiu no século XVI, com o colonizador que nos explorou, e agora com o Primeiro Mundo que nos mantém em situação de dependência. A comemoração da origem é problemática: comemorar a Descoberta é comemorar um massacre, comemorar a Independência é lembrar o quanto esta é factícia.

Apesar de tudo, uma cultura, ou mais precisamente várias culturas se constituíram nos países latino-americanos. Tendo ultrapassado há muito, no terreno da política formal, as etapas do nacionalismo libertador, falta-nos adquirir uma verdadeira atitude pós-colonial no que se refere à cultura. Resta-nos assumir "uma terceira natureza, que não é arcaica e pré-histórica, mas que deriva historicamente e por abdução das privações do presente" (35).

Dependendo (36) do Outro, como todo o desejo, o desejo dos mais nacionalistas dos latino-americanos é, a miúdo, que a sua cultura seja, não só reconhecida, mas admirada pelo Primeiro Mundo. Isto afecta a própria produção da literatura latino-americana, na medida em que a recepção internacional the é mais 
favorável quando ela responde aos desejos de evasão, de exotismo e de folclore das culturas hegemónicas. Os escritores menos típicos (typés) não alcançam mais que um êxito de estima e atingem um público muito mais restrito. O grande público do Primeiro Mundo quer que os latino-americanos sejam pitorescos, coloridos e mágicos, têm dificuldade em vê-los como iguais não completamente idênticos, $o$ que, diga-se, nos autorizam as nossas origens e a nossa história.

Condenados ao paradoxo, os melhores escritores latino-americanos compreenderam que podiam e deviam tirar partido dele. Não tendo já curso as teorias evolucionistas do homem e da sociedade, a diversidade e a pluralidade podem afirmar-se sem complexos. Encontrando-se a doxa hegemónica actualmente em crise de legitimidade e de eficácia, a para-doxa latino-americana pode construir uma instância crítica e libertadora para as próprias culturas hegemónicas. Inventada pela Europa como um mundo ao lado, a América teve sempre essa tendência, voluntária ou involuntária, de ser a paródia da Europa. Como toda a antiga colónia, a América é necessária à Europa como um espelho. Que o espelho adquira uma perturbadora autonomia, tornando-se deformante, que devolva uma imagem ao mesmo tempo familiar e estranha, é esse o risco ou a fatalidade de toda a procriação ilegítima. $\mathrm{O}$ desforço do filho não consiste em ruminar indefinidamente $\mathrm{O}$ ressentimento relativo à sua origem, mas em reivindicar a herança e gozá-la livremente, em fazê-la prosperar, acarreando para ela preciosas diferenças linguísticas e culturais.

Notas

1 A questão do pós-colonialismo tem sido debatida ultimamente na crítica literária anglosaxônica, com ampla repercussão editorial. Veja-se, a título de exemplo: Gayatri Chakravorty Spivak, The post-colonial critic, New York/London, Routledge, 1990; Terry Eagleton, Fredric Jameson, Edward Said, Nationalism, colonialism and literature, Minneapolis, University of Minnesota Press, 1990; Homi K. Bhabha (ed.), Nation and narration, London/New York, Routledge, 1990.

2 Doris Sommer, Irresistible romance: the foundational fictions of Latin America. In: Homi K. Bhabha, Nation and narration, cit.

3 Sérgio Buarque de Holanda, Raizes do Brasil [1936], 14 a ed., Rio de Janeiro, José Olympio, 1981, p.3.

4 Conferência no Collège de France, Paris, janeiro de 1983.

5 Discurso pronunciado por el Libertador ante el Congreso de Angostura, 15 de febrero de 1819, día de su instalación. In: Proclamas y discursos del Libertador, Vicente Lecuna (ed.), Caracas, Tip. del Comercio, 1939, p. 202-235.

6 Ver Antonio Candido, Formação da literatura brasileira [1959], $3^{\text {a }}$ ed., São Paulo, Martins Fontes, 1969.

7 Ver Pedro Enríquez Ureña, Las corrientes literarias en la América Hispánica, $3^{\text {a }}$ ed., México, Fondo de Cultura Económica, 1964. $1^{\text {a }}$ ed: Literary currents in Hispanic America, Cambridge Mass., Harvard University Press, 1945. 
8 Ernesto Sábato, La cultura en la encrucijada nacional, $5^{\text {a }}$ ed., Buenos Aires, Editorial Sudamericana, 1983, p. 144.

9 Domingo Faustino Sarmiento, Facundo [1845], Buenos Aires, Editorial Losada, 1976.

10 José Enrique Rodó, Ariel - A la juventud de América [1900]. In: Obras completas, Madrid, Aguilar, 1957.

11 Richard Morse, O espelho de Próspero, São Paulo, Companhia das Letras, 1988.

12 José Martí, Nuestra América [1891]. In: Política de nuestra América, Mexico, Siglo XXI, 1982, p.37-44.

13 Ver Ernest Gellner, Nations and nationalism, Oxford, Basil Blackwell, 1983; Benedict Anderson, Imagined communities: reflections on the origin and spread of nationalism, London, Verso, 1983.

14 Jorge Luis Borges, Discusión [1932], Madrid-Buenos Aires, Alianza-Emecé, 1976, p. 132 .

15 Lima Barreto, O triste fim de Policarpo Quaresma [1915], São Paulo, Brasiliense, 1965 , p. 285

16 Mário de Andrade, Improviso do mal da América, [Remate de males, 1930]. In: Poesias completas, Diléa Zanotto Manfio (ed.), Belo Horizonte, Itatiaia-Edusp, 1987, p. 266.

17 Ver Pierre Rivas, Paris como a capital literária da América Latina. In: Literatura e história na América Latina, Lygia Chiappini \& Flávio Aguiar (eds.), São Paulo, Edusp, 1993.

18 Ver Lévi-Strauss, Race e culture [1971]. In: Le regard éloigné, Paris, Plon, 1983; Race et histoire, Paris, Denoel-Gonthier, 1981.

19 El signo y el garabato, Mexico, Joaquin Mortiz, 1973.

20 Ver Emir Rodríguez Monegal \& Leyla Perrone-Moisés, Lautréamont austral, Montevideo, Brecha, 1995, p. 83.

21 Prólogo de El reino de este mundo [1949], Montevideo, Arca, 1968.

22 Autonomía literaria americana. In: Sin nombre, v. XII, n. 4, San Juan - Puerto Rico, 1982; Sistema literario y sistema social en Hispanoamérica. In: Literatura y praxis en América Latina, Caracas, Monte Avila, 1975.

23 Havana, Instituto Nacional de Cultura, 1957.

24 Da razão antropofágica: diálogo e diferença na cultura brasileira [1980]. In: Metalinguagem é outras metas, $4^{\text {a }}$ ed., São Paulo, Perspectiva, 1992, p. 236-237.

25 América Latina: palavra, literatura e cultura, Ana Pizarro (org.), v. I, A situação colonial, Campinas, Unicamp-Memorial, 1993, p. 25 e 37.

26 Darcy Ribeiro, As Américas e a civilização, Petrópolis, Vozes, 1977, p. 465: "O processo de maturação étnico-nacional dos rioplatenses está incompleto", em virtude de uma "postura européia".

27 Harold Bloom, The anxiety of influence, New York, Oxford University Press, 1973.

28 Mexico, Fondo de Cultura Económica, 1950. 
29 Puertas al campo [1966], Barcelona, Seix Barral, 1972, p. 9-10.

30 La cultura en la encrucijada nacional, p. 7.

31 Id., p. 80.

32 Discusión, p. 137.

33 Nationalism: irony and commitment. In: Terry Eagleton, Fredric Jameson \& Edward Said, Nationalism, colonialism and literature, p. 23 a 39.

34 Veja-se, a título de exemplo, a metáfora do Barroco como “o ouro roubado" pelos americanos aos europeus, no ensaio de Severo Sarduy, Lautréamont y el barroco. In: Emir Rodríguez Monegal \& Leyla Perrone-Moisés, Lautréamont austral, p. 117.

35 Nationalism, colonialism and literature, p. 79.

36 A partir daqui a ortografia lusitana e a provável melhora de estilo se devem ao seguinte: estes dois parágrafos finais foram traduzidos por José Saramago, que me deu a honra de os verter e citar em Cadernos de Lanzarote - Diários II, Lisboa, Editorial Caminho, 1995, p. 179-180. Saramago estava presente, como escritor homenageado, no Congresso em que fiz esta conferência.

Leyla Perrone-Moisés, professora da USP e escritora, é coordenadora do NuPEBrap (Núcleo de Pesquisa Brasil-França, criado em agosto de 1988 no Instituto de Estudos Avançados da USP)

O artigo é a tradução de uma conferência plenária pronunciada em francês pela autora no $14^{\circ}$ Congresso da Associação Internacional de Literatura Comparada em Edmonton, Canadá, em agosto de 1994. O texto aqui apresentado foi levemente alterado, já que a exposição para um público internacional exigia informações dispensáveis para o público brasileiro e, inversamente, algumas questões mereciam, neste caso, maior desenvolvimento. Versão em inglês foi publicada em: Maria Elena Valdés, Mário J. Valdés \& Richard A. Young (eds.), Latin America as its literature, New York, Council on National Literatures, 1995, p. 36 a 54. 